\title{
Antimicrobial effect of some Egyptian plants
}

\author{
Araf A. Amin, Atef H. El-Sayed, Mervat A. Foad and Osama.A.Rashwan
}

NATIONAL NUTRITION INSTITUTE

\begin{abstract}
Twenty eight crude water extracts of four Egyptian plants: Hibiscus sabdariffa (Karkade), Tamarindus indica (Tamarind), Glycyrrhiza glabra (Liquorice) and Ceratonia siliqua (Carob) , were tested for their antibacterial activities against 10 common pathogenic bacteria,Bacillus cereus, Shigella flexenary and Escherichia coli showed sensitivity to the 28 extracts. Shigella sp. showed sensitivity to 24 extracts while Pseudomonas sp. and Salmonella typhimurium were sensitive to 23 extracts. Salmonella paratyphi and Aerobacter aerogenes showed sensitivity to 22 extracts, Serratia marcesence and Aeromonas hydrophila showed sensitivity to 20 extracts. Karkade exhibited marked antibacterial activity against all the 10 organisms. E. coli and Shigella flexenary had no observed sensitivity to Liquorice extracts. Aerobacter aerogenes was the only one which had no observed sensitivity to Tamarind extracts. All the extracts of Carob were effective against only two pathogens:Bacillus cereus and Shigella flexenary. The results support the traditional uses of extracts of these plants for the management of bacterial infections and for the development of antibacterial agents for the preservation of foods.
\end{abstract}

\section{Introduction:}

Herbal medicine depends on the action of non-essential nutrients and the phytochemical (Walker, 2006).Liquorice has been used as medicine in China for centuries. It may be taken by mouth to treat stomach conditions such as ulcers and respiratory conditions as bronchitis and it may be anti-infective and anti-inflammatory (Frus-Moller et al., 2002). Two compounds from Liquorice inhibit the growth of Streptococcus mutans, the primary bacteria responsible for causing cavities. In fact, Liquorice roots antimicrobial activity was seen in a number of experiments (Sahelian, R., 2005).

Polyphenols in Carob possess antibacterial and anti-inflammatory effects. Substantial in vitro and animal studies support the beneficial effects of polyphenols in many gastrointestinal diseases (Dryden et al., 2006). Evans et al. (2002), Ganamoni et al.(2003), Khan et al. (2003), Matu and Staden (2003) and Ram et al. (2004) detected antibacterial substances in some plant 
extracts and their effects on some pathogenic microorganisms as Salmonella typhi Staphylococcus aureus, Pseudomonas spp. and Bacillus spp. in vitro.

Nowadays, there is an increasing trend throughout the world to go back to nature. Egypt is not far from what is happening in the whole world. The writings on the papyrus and temple walls showed that Ancient Egyptians were aware of the usefulness of many plants and used some of them for the same purposes as they are used today (C.A.P.A.,2000).In Ancient Egypt, spices and condiments were used as embalming materials, as sweet scents in religious ceremonies and to mask the putrid flavor of meat in hot climates lacking refrigeration (I.C.M.S.F., 1980). Also different medical preparations containing aromatic plants extracts are now produced at mass production scale and a few plants have an antimicrobial effect at the concentrations used in food and thus serve as preservatives.

Bepoliver-Bevere (1986) mentioned that the plant constitutes with antibacterial action are tentatively grouped according to their main chemical groups: phenols, quinines, acids, alkaloids, flavonoides, terpenoids and proteolytic enzymes. Alian and Eid (1983) reported that Tamarind beverage had a bacteriostatic effect at concentration as low as $0.75 \%$ on Klebsiella pneumoniae, $1 \%$ on E. coli , $4 \%$ on Bacillus subtilis and S.typhi giving inhibition zones of $10 \mathrm{~m} . \mathrm{m}$. . Inhibition depended on concentration of Tamarind and on the tested organisms. Ethanol extract from Tamarind was the most effective inhibitor against all tested organisms, while chloroform extract had the least inhibitory effect.

Ray and Majumdar (1976) reported that ethanol 95\% extract of fruit of Tamarind on agar plate was active on Bacillus subtilis , E. coli , Salmonella typhosa , Staphylococcus aureus and Vibrio cholera. On the other hand, Ross et al. (1980) found that acetone extract of Tamarind fruit on agar plate was active on S, typhimurium, while ethanol $70 \%$ extract was active on $\mathrm{B}$. cereus, $\mathrm{B}$. megaterium, E. coli , Pseudomonas aeruginosa, S. typhimurium, Staph. albus and Staph. Aureus

Neidhardt et al. (1990) mentioned that, the wall of a typical Gram- negative cell consists a single, gigantic and sac like molecule of murein, of one or few layers thick while the wall of a Grampositive cell, e.g. B.subtilis or Staphylococci, is made up of many layers of murein plus teicholic acids. These variations between the cell wall structure of Gram-negative and-positive bacteria may act as a limiting factor in controlling the level of saponin interaction or penetration within these two bacterial groups. 
Gamal (1992) showed that bacteria, in general was more resistant to the applied concentrations of saponin when compared with fungi, a fact which may be due to lack of sterols in bacteria. On the other hand, Leath et al. (1972) reported that saponins inhibit growth of some microorganisms which lack sterols in their cell membrane.

Haraguchi et al. (1998) examined the antimicrobial activity of retrochalcones, licochalcone A , B , C and D and echinatin isolated from the roots of Glycerrhiza inflate " a source of Liquorice" and showed that they inhibited the growth of Gram-positive bacteria . Abo EI-Azm (1999) showed that cool aqueous extract of Liquorice inhibited the growth of S.aureus, B.cereus, B. subtilis , Proteus mirabilis, Salmonella typhimurium and E. coli. He also mentioned that the higher the concentration, the more inhibition zone for all organisms. The two major constituents of Liquorice are glycyrrhizin and flavonoids. According to test tube studies, glycyrrhizin has anti-inflammatory actions and may inhibit the breakdown of the cortisol produced by the body. Liquorice may also have antiviral, antioxidants and work to protect liver cells. In the test tubes, the flavonoides have been shown to kill Helicobacter pylori, the bacteria that cause most ulcers and stomach inflammation (Josephs et al., 2001, Beil et al., 1995, Amer and Metwalli, 2000.

Leob et al. (1989) reported that the main constituents of Carob are sugars and tannins. Carob tannins have an astringent effect in the gastrointestinal tract making them useful for treating diarrhea. They may also bind to (and thereby inactivate) toxins and inhibit growth of bacteria. The sugar makes Carob gummy and able to act as thickener to absorb water, another action that may help decrease diarrhea. Oboh and Elusiyan (2004) reported that the antimicrobial effect of the unfortified roselle extract was low against the entire organisms.

Imbabi et al. (1992) mentioned that Tamarind seed extracts have recently been strong antimicrobial action against E. coli and may be due to tamarindineol (5-hydroxy-2-oxo-hexa-3, 5dienol). Antimicrobial properties of plants are desirable tools in the control of undesirable microorganisms especially in the treatment of infections and in food spoilage (Aboaba et al. 2006).

This study is aimed to determine the rate of susceptibility of 10 organisms to the aqueous extracts of the tested 4 Egyptian plants for use as therapeutic agents. 


\section{Matrerial and Methods}

The antibacterial effect of aqueous extract of Karkade"Hibiscus sabdariffa", Tamarind'Tamarindus indica", Liquorice"Glycyrrhiza glabra"and Carob"Ceratonia siliqua" were tested againet 10 selected ofganisms : Aeromonas hydrophlla, Bacillus cereus, Aerobacter aerogenes, Escherichia coli , Pseudomonas sp., Salmonella typhimurium, Salmonella paratyphi, Serratia marcesence. Shigella flexenary and Shigella $\mathrm{sp}$. The investigated plants were obtained from Faculty of Pharmacy Farm, Giza, Cairo University. The tested microorganisms were kindly provided from Faculty of Agriculture, Cairo University and National Institute of Diabetes and Endocrine Glands, on nutrient agar slants at 4degree $c$. Each organism was transferred to tryptic scy broth with $0.6 \%$ yeast extract (Dlico) and grown for $24 \mathrm{~h}$. at 30 degree $\mathrm{c}$. before use.

\section{Preparation of plant extracts:}

1a - A $100 \mathrm{~g}$. of dried plant added to $1 \mathrm{~L}$ boiled distilled water in a sterile flask.

1b - The content ves filtered and the extract used in the experiments.

2. Repeat (ia), the flesk was left for to min., and then fitered.

3- In another flask add $1 \mathrm{~L}$ cold distilled water on the same amount of plant, then filtered and the extract used in the experiments.

4 - As in (3) but teft for $6 \mathrm{~h}$.

5 . As in (3) but left for $12 \mathrm{~h}$.

6 - As in (3) but left for $18 \mathrm{~h}$.

7 - As in (3) but left for $24 \mathrm{~h}$.

then filiered after each time and the extracts used in the experiments.

\section{Asxipmicroblal activity:}

It was tested using agar diffusion assay (Abou Zeid and Shehata, 1969, Aboaba et al. 2008) 0.2 $\mathrm{ml}$ of a $24 \mathrm{~h}$ broth culture of pathogens were aseptically introduced and evenly spread using bent sterile glass rod on the surface of sterile Muelter-hinton agar plates. Three wells of $6.0 \mathrm{~mm}$ in diameter were aseptically punched on each agar plate using a sterile cork bore. Fixed volume $(0.1 \mathrm{ml})$ of the plant extracts was carefully placed in each well. The plates were incubated at 37 degree $c$. for $24 \mathrm{~h}$. The zone of inhibition of each well was obtained by measuring the underside of the plate in two planes with a ruler calibrated in millimeter. The control was placed with $0.1 \mathrm{ml}$ of distilled water and incubated. 


\section{Results and Discussion}

Twenty eight aqueous extracts of four Egyptian plants were tested for their antibacterial activity against 10 pathagenic bacteria. $10 \%$ concentrate extracts of various plants were used for testing antibacterial potential. The four plants were found to have inhibitory effect against bacteria. Tables 1-4 show that water extracts of Hibiscus sabdariffa, Tamarindus indica, Glycyrrhiza glabra and Ceratonia siliqua exhibited antibacterial activity.

Ceratonia siliqua (Carob) extracts are the highest effective against Bacillus cereus (Table 4 and Fig. 4) specially the cold aqueous extract, left for $18 \mathrm{~h}$. then filtered, (diameter of the inhibition zone was $42 \mathrm{~mm}$.). Also all the different aqueous extracts of this plant inhibit the growth of Shigella flexenary (mean inhibition zone was $17.8 \mathrm{~mm}$.). All the Carob extracts had no activity against Serratia marcesence and Aeromonas hydrophila .Kivcak et al. (2002) found that the ethanol extract of Carob inhibited the growth of five of the 10 microorganisms but had no effect on the growth of E. coli, Staphylococcus aureus, Enterococcus faecalis or Pseudomonas aeruginosa.

Tables 1and 3 showed the effect of Liquorice on growth of all the tested organisms. The Seven extracts of each plant were able to produce clear zones on all the ten strains used indicating bactericidal activity. S. typhimurium was the most sensitive of the boiling water extract of Liquorice, the agar diffusion test results showed the presence of a wide zone of inhibition $-23 \mathrm{~mm}$.of $\mathrm{S}$. typhimurium , $15 \mathrm{~mm}$. of $S$. paratyphi- surrounding the agar wells indicating antisalmonellic activity, followed by Pseudomonas sp. $(20 \mathrm{~mm}$. in diameter) . Cold water extract of Liquorice inhibited the growth of B. cereus, the diameter size of inhibition zone was $23 \mathrm{~mm}$.(as show in Fig. 1, Table 1).

Liquorice is one of the most extensively used and scientifically investigated herbal medicines. Its traditional uses include the treatment of peptic ulcers, asthma, pharyngitis, malaria, abdominal pain, insomnia and infections. Abo El-Azm(1999) showed that aqueous extract of Liquorice inhibited the growth of $S$. typhimurium, Staphylococcus aureus, B. cereus and $E$. coli. The majority of its anti-microbial effects are due to its isoflavanoid components. Chemical investigations have revealed the presence of a wide variety of bioactive phenolic constituents in liquorice; these have attracted attention as a potential source of activity against all tested organisms specially S. typhimurum and B.cereus (Tsukiyama, et al. , 2002).

The aqueous extract of Hibiscus sabdariffa, as in Owulade et al. (2004), inhibited effectively the growth of all tested bacterial pathogens, caused inhibition zones measuring $10-40 \mathrm{~mm}$. Boiling water extract of this plant appeared to be the most effective on $B$. cereus (diameter of the inhibition 


\section{Afaf A. Amin et al}

zone was $40 \mathrm{~mm}$.), resuits from the antimicrobial screening tests are shown in Table (3). Moderate antimicrobial activity was shown by Karkade extracts on Shigella flexenary (mean diameters of the inhibition zones was 20.29mm.), Pseudomonas sp.(19,71mm.), Shigella sp.(18.71 $1 \mathrm{~mm}$.) and on $E$. coli $(17.86 \mathrm{~mm}$.) .Extracts of the roots were effective against bacteria that may cause diarrhea as Escherichia coli, Saimonella typi, and Vibrio cholera thus supporting the traditional uses for this purpose (Ajagbonna et al. 2001, Moshi et al., 2006).

The in vitro inhibitory effect of Karkade on the growth of Staphylococcus aureus, Klebsiella pneumoniae, Pseudomonas aeruginosa and Acinetobacter baumannii was studied by Liu et al.(2005) . The data from inhibition zone values showed that roselle calyx (Karkade) extract inhibited effectively the growth of all test bacterial pathogens as in our results.The antibacterial effect of this plant may be due to saponins and tartaric acid. Oboh and Elusiyan (2004) mentioned that fortification of roselle extract with pineapple juice and lemon grass greatly enhanced the inhibition of the growth of Bacillus sp., Pseudomonas aeruginosa, Lactobacillus sp. and Corynebacterium sp.

Burkholderia pseudomallei cause melioidosis, a life-threatening infection common among paddy cultivators in Southeast Asian countries. No plant materials have been investigated for its activity against Burkholderia pseudomallei. Therefore, a preliminary study was carried out using disc diffusion. Only methanol leaf extracts of Tamarindus indica exhibited anti-B. pseudomallei activity (Muthu ot al. , 2005) . They found that the leaves of T. indica could be an important source of new antimicrobial agent against Burkholderia pseudomallei .

In our study cold water (left 12,18,24h. then filtered) extracts of Tamarindus indica, as in Table(2), Fig 2, inhibit the growth of Pseudomonas sp.(the inhibition zone was $20 \mathrm{~mm}$. for each extract). Also Hibiscus sabdariffa and Glycyrrhiza glabra succeed to show zones of inhibition of the organism (Tables1 and 3). Boiling water extract of Tamarindus indica was the most effective on B. cereus (Table 2). Tamarindus indica extracts have antimicrobial activities against all the ten bacteria except its cold water extract on Aeromonas hydrophila, Aerobacter aerogenes, $S$. paratyphi and Serratia marcesence .Imbabi et al. (1992) mentioned that the antibacterial effect of Tamarind may be due to tamarindineol.

Only one extract (boiling water extract) out of 7 derived from Carob showed an antimicrobial activity against S. paratyphi (Table 4).To evaluate the effects of herbal extracts derived from plants commonly prescribed by traditional practitioners for the treatment of typhoid fever (Nkuo-Akenji et 


\section{Egyptian J. of Nutrition and Health Vol. 1 No. 1 (2006)}

al., 2001), the 4 plants were tested for antibacterial activity against Salmonella paratyphi and S. typhimurium. S. paratyphi was most sensitive to boiling water, left for $10 \mathrm{~min}$., then filtered, extract of Glycyrrhiza glabra(Liquorice) and Hibiscus sabdariffa (Karkade), also to cold water, left for $6 \mathrm{~h}$ and $24 \mathrm{~h}$. , then fitered, extracts of Glycyrrhiza glabra. While S. typhimurium was most sensitive to boiling water extract of Glycyrrhiza glabra. Ceratonia siliqua (Carob) did not show effect on the two pathogens.

Of the 28 extracts, B. cereus, Shigella flexenary and E.coli were sensitive to all extracts with diameters of inhibition zones ranging from $10-42 \mathrm{~mm}$, as shown on Tables $(6,13$ and 8 ), respectively. Eight extracts showed no inhibition of growth of each: Aeromonas hydrophila and Serratia marcescens i.e. all extracts of Carob and one of Tamarind (Table 5, 12). Pseudomonas was sensitive to twenty three extracts (Table 9) and no effect with cold water extracts of Carob.Karkade produced the highest zones of inhibition (average of inhibition zone was $19.71 \mathrm{~mm}$.) against Pseudomonas.

S. typhimurium and $S$. paratyphi were not sensitive to any of the Carob extracts, except some low effects with few extracts only (Tables 10,11). We observed zones of inhibition, ranging from $10-24 \mathrm{~mm}$, for twenty four extracts against Shigella sp. (Table 14). Tabie (7) shows that the zones of inhibition of the bacteria Aerobacter aerogenes ranging from $11-20 \mathrm{~mm}$. Cold water extracts of Carob showed no inhibitory effects against Aerobacter aerogenes .

The most effective method of extraction which gave the highest zone of inhibition (more than or equal $15 \mathrm{~mm}$.) against the tested bacteria are shown in tables and figures (5-14)

\section{A) Liquorice:}

${ }^{*} E$. coli and Shigella flexenary had no observed sensitivity to all extracts of this plant.

1-- Boiling water extract, is effective against

$\begin{array}{lll}\text { Salmonella typhimurum } & \text { Bacillus cereus } & \text { Pseudomonas sp. } \\ \text { Salmonella paratyphi } & \text { Aeromonas hydrophila }\end{array}$

2-- Boiling water extract, left for 10 min. then filtered, is effective against

$\begin{array}{lll}\text { Salmonella typhimurum } & \text { Bacillus cereus } & \text { Pseudomonas sp. } \\ \text { Salmonella paratyphi } & \text { Aeromonas hydrophila } & \text { Aerobacter aerogenes }\end{array}$

3-Cold water extract, is effective against

Bacillus cereus

Aerobacter aerogene
Shigella sp. 
4- Cold water extract, left for 6 hi.then filtered is effective against

$\begin{array}{ll}\text { Salmonella typhimurum } & \text { Shigella sp. Salmonella paratyphi } \\ \text { Serratia marcesence } & \text { Aerobacter aerogenes }\end{array}$

5-Cold water extract, left for $12 \mathrm{~h}$.then filtered is effective against

Salmonella typhimurum Pseudomonas sp. Aerobacter aerogenes Shigella sp.

Salmonella paratyphi Serratia marcesence

Aeromonas hydrophila

Bacillus cereus

6-Cold water extract, left for $18 \mathrm{~h}$.then filtered is effective against

Salmonella typhimurum Shigella sp. Aerobacter aerogenes Bacillus cereus

Salmonella paratyphi Serratia marcesence

7-- Cold water extract, left for $24 \mathrm{~h}$.then filtered is effective against

Salmonella typhimurum Shigella sp. Salmonella paratyphi

Aerobacter aerogenes Bacillus cereus

\section{B) Tamarind:}

*Aerobacter aerogenes had no observed sensitivity to the extracts of this plant.

1-Boiling water extract, is effective against

Salmonella typhimurum Pseudomonas $\mathrm{sp}$ Bacillus cereus

Shigella flexenary

2-- Boiling water extract, left for $10 \mathrm{~min}$. then filtered, is effective against

As in 1-w without Salmonella typhimurum

3-- Cold water extract, is effective against

Shigella sp. Only

4- Cold water extract, left for 6h.then filtered, is effective against

Pseudomonas sp. Bacillus cereus Shigella flexenary 


\section{Egyptian J. of Nutrition and Health Vol. 1 No. 1 (2006)}

5-Cold water extract, left for $12 \mathrm{~h}$.then filtered, is effective against

Pseudomonas sp.

Shigella sp

Shigella flexenary

Bacillus cereus

E. coli

Aeromonas hydrophila

Serratia marcesence

6-- Cold water extract, left for 18h.then filtered, is effective against

Pseudomonas sp.

Bacillus cereus

Shigella sp.

7-- Cold water extract, left for $24 \mathrm{~h}$.then filtered, is effective against
Pseudomonas sp.
Salmonella typhimurum
S. paratyphi
Bacillus cereus
Shigella $\mathrm{sp.}$
Shigella flexenary

\section{C) Karkade:}

*The 10 tested bacteria were inhibited

*All the 7 extracts of this plant were effective on the growth of:-

Pseudomonas sp. Shigella flexenary

Bacillus cereus Shigella sp.

Beside, the extracts are also effective against other bacteria as follows:

1-- Boiling water extract:
S. paratyphi
Aerobacter aerogenes
Serratia marcesence

2-- Boiling water extract, left for $10 \mathrm{~min}$. then filtered:
S. paratyphi
E. coli
Aeromonas hydrophi
Serratia marcesence

3-- Cold water extract:
S. paratyphi
E. coli

4-- Cold water extract, left for 6 h.then filtered:
S. paratyphi
Serratia marcesence
E. coli

5-- Cold water extract, left for $12 \mathrm{~h}$.then filtered:

E. coli

Aeromonas hydrophila

Serratia marcesenc

Aerobacter aerogenes 
Afaf A. Amin ef al

6-- Cold water extract, left for $18 \mathrm{~h}$.then filtered:

Salmonella typhimurum E. coli

7-- Cold water extract, left for $24 \mathrm{~h}$.then filtered:

Salmonella typhimurum Serratia marcesence E. coli

S. paratyphi Aerobacter aerogenes

D) Carob:

*All the extracts of this plant were effective against only these two pathogens:

Bacillus cereus Shigella flexenary

The most effective extracts which inhibit (the diameter of inhibition zone more than or equal $15 \mathrm{~mm}$.) the tested bacteria as shown in tables and figures (5-14) were as follows:

Aeromonas hydrophila:

Liquorice

- Boiling water extract, filtered directly.

Liquorice or Karkade

- Boiling water extract, left for $10 \mathrm{~min}$., then filtered.

Liquorice, Tamarind or Karkade

- Cold water extract, left for $12 \mathrm{~h}$. , then filtered

Bacillus cereus:

Liquorice, Tamarind, Karkade or Carob

- Boiling water extract (or) Boiling water extract, left for $10 \mathrm{~min}$., then filtered .

Liquorice

- Cold water extract (or) Cold water extract, left for $12 \mathrm{~h}$. or $18 \mathrm{~h}$. or $24 \mathrm{~h}$. , then filtered.

Tamarind, Karkade and Carob

- Cold water extract, left for $6 \mathrm{~h}$. or $12 \mathrm{~h}$. or $18 \mathrm{~h}$. or $24 \mathrm{~h}$. , then filtered.

Aerobacter aerogenes

Liquorice

- Boiling water extract, left for $10 \mathrm{~min}$., then filtered

- Cold water extract, left for $6 \mathrm{~h}$. or $12 \mathrm{~h}$. or $18 \mathrm{~h}$. or $24 \mathrm{~h}$. , then filtered.

Karkade

- Boiling water extract, filtered directly.

- Cold water extract, left for $12 \mathrm{~h}$. or $24 \mathrm{~h}$. , then filtered.

E. coli

Tamarind 


\section{Egyptian J. of Nutrition and Health Vol. 1 No. 1 (2006)}

- Cold water extract, left for $12 \mathrm{~h}$, , then filtered

\section{Karkade}

- Boiling water extract, left for 10 min., then filtered.

- Cold water extract (or) Cold water extract, left for $6 \mathrm{~h}$. or $12 \mathrm{~h}$. or $18 \mathrm{~h}$. or $24 \mathrm{~h}$. , then filtered Pseudomonas sp.

Liquorice, Tamarind, Karkade

- Boiling water extract (or) boiling watei extract, left for 10 min., then filtered.

Liquorice

- Cold water extract, left for $12 \mathrm{~h}$, , then iiltered

Tamarind or Karkade

- Cold water extract, left for $6 \mathrm{~h}$. or $12 \mathrm{hi}$. or $18 \mathrm{~h}$. or $24 \mathrm{~h}$. , then filtered

Karkade

- Cold water extract, filtered directly.

Salmonella typhimurum

Liquorice

- Boiling vater extract (or) boiling water extract, left for $10 \mathrm{~min}$, then filtered

- Cold water extract, left for $6 \mathrm{~h}$. or $12 \mathrm{~h}$. or $18 \mathrm{~h}$. or $24 \mathrm{~h}$, then filtered

Tamarind

- Boiling water extract, then filtered

- Cold water extraci, left for $24 \mathrm{~h}$. , then filtered

\section{Karkade}

- Cold water exiract, left for $18 \mathrm{~h}$. or $24 \mathrm{~h}$, then filtered

S. paratyphi

\section{Liquorice and Karkade}

- Boiling water extract (or) boiling water extract, Jeft for $10 \mathrm{~min}$., then filtered.

Liquorice

- Cold water extract, left for $6 \mathrm{~h}$. or $12 \mathrm{~h}$. or $18 \mathrm{~h}$. or $24 \mathrm{~h}$. , then filtered

\section{Tamarind}

- Cold water extract, left for $24 \mathrm{~h}$. , then filtered

Karkade

- Cold water extract (or) Cold water extract, left for $6 \mathrm{~h}$. or $24 \mathrm{~h}$. , then filtered

\section{Serratia marcesence}

Liquorice

- Cold water extract, left for $6 \mathrm{~h}$. or $12 \mathrm{~h}$. or $18 \mathrm{~h}$. , then fitered 
Tamarind

- Cold water exiract, left for $12 \mathrm{~h}$. , then filtered

Karkade

- Boiling water extract (or) boiling water extract, left for $10 \mathrm{~min}$., then filtered

- Cold water extract, left for $6 \mathrm{~h}$. or $12 \mathrm{~h}$. or $24 \mathrm{~h}$., then filtered

Shigella ilexenary

Tamarind, Karkade and Carob

- Boiling water extract (or) boiling water extract, left for $10 \mathrm{~min}$., then filtered

Tamarind

- Cold water extract, left for $6 \mathrm{~h}$. or $12 \mathrm{~h}$, then filtered

Karkade and Carob

- Cold water extract (or) Cold water extract, left for $6 \mathrm{~h}$. or $12 \mathrm{~h}$. or $18 \mathrm{~h}$. or $24 \mathrm{~h}$, , then filtered

Shigella sp.

Liquorice, Tamarind or Karkade

- Cold water extract, filtered directly.

Liquorice or Karkade

- Cold water extract, left for $6 \mathrm{~h}$. or $12 \mathrm{~h}$. or $18 \mathrm{~h}$. or $24 \mathrm{~h}$. , then filtered

Tamariind

- Cold water extract, left for $12 \mathrm{~h}$. or $18 \mathrm{~h}$. or $24 \mathrm{~h}$. , then filtered

Karkade

- Boiling water extract (or) boiling water extract, left for $10 \mathrm{~min}$., then filtered

Antimicrobial properties of plants are desirable tools in the control of undesirable microorganisms especially in the treatment of infections and in food spoilage (Aboaba et al. 2006)

It is necessary to fractionate the most active bactericidal extracts to better assess the activity of their components. Some of the plant extracts tested in this work may contain compounds with selective action against certain bacteria, this may account for the traditional use as medicinal plants (Aies and Erdogrul, 2003, Moses et al. 2006).

In conclusion, the antimicrobial activity observed on the tested extracts may provide useful data for the utilization of antimicrobial principles of these aqueous extracts. 
Egyptian J. of Nutrition and Health Vol. 1 No. 1 (2006)

Table (1): Antibacterial activity (as inhibition zone) of LIQUORICE extracts on the tested organisms

\begin{tabular}{|c|c|c|c|c|c|c|c|c|c|c|}
\hline $\begin{array}{l}\text { The different } \\
\text { methods used }\end{array}$ & $\begin{array}{c}\text { A. } \\
\text { hydr. }\end{array}$ & $\begin{array}{c}\text { B. } \\
\text { cer. }\end{array}$ & $\begin{array}{l}\mathrm{Ae} . \\
\text { aer. }\end{array}$ & E. coli & Ps. sp. & $\begin{array}{c}\text { S. } \\
\text { typhim. }\end{array}$ & para. & $\begin{array}{l}\text { Se. } \\
\text { mat. }\end{array}$ & $\begin{array}{l}\text { Sh. } \\
\text { flex. }\end{array}$ & $\begin{array}{l}\text { Sh. } \\
\text { sp. }\end{array}$ \\
\hline $\begin{array}{l}\text { Add boiling } \\
\text { water }\end{array}$ & 16 & 21 & 14 & 10 & 20 & 23 & 15 & 13 & 10 & 12 \\
\hline $\begin{array}{l}\text { Add boiling } \\
\text { water, left } \\
\text { forio min. }\end{array}$ & 16 & 22 & 15 & 10 & 19 & 20 & 20 & 13 & 10 & 12 \\
\hline Add cold water & 10 & 23 & 20 & 10 & 11 & 14 & 14 & 11 & 10 & 15 \\
\hline $\begin{array}{c}\text { Add cold } \\
\text { water, left for } 6 \\
\text { h. }\end{array}$ & 13 & 15 & 16 & 10 & 14 & 16 & 20 & 16 & 11 & 15 \\
\hline $\begin{array}{c}\text { Add cold } \\
\text { water, left for } \\
12 \mathrm{~h} .\end{array}$ & 16 & 15 & 16 & 10 & 15 & 17 & 15 & 16 & 13 & 15 \\
\hline $\begin{array}{c}\text { Add cold } \\
\text { water, left for } \\
18 \mathrm{~h} .\end{array}$ & 10 & 15 & 16 & 10 & 13 & 20 & 15 & 16 & 14 & 15 \\
\hline $\begin{array}{c}\text { Add cold } \\
\text { water, left for } \\
24 \mathrm{~h} .\end{array}$ & 10 & 16 & 20 & 10 & 13 & 17 & 20 & 12 & 10 & 18 \\
\hline
\end{tabular}

Zone of Inhibition $=$ or $>10 \mathrm{~mm}$ was considered sensitive

Table (2): Antibacterial activity (as inhibition zone) of TAMARIND extracts on the tested organisms

\begin{tabular}{|c|c|c|c|c|c|c|c|c|c|c|}
\hline $\begin{array}{c}\text { The different } \\
\text { methods used }\end{array}$ & $\begin{array}{c}\text { A. } \\
\text { hydr. }\end{array}$ & $\begin{array}{c}\text { B. } \\
\text { cer. }\end{array}$ & $\begin{array}{c}\text { Ae. } \\
\text { aer. }\end{array}$ & E. coli & Ps. spp. & $\begin{array}{c}\text { S. } \\
\text { tyohim. }\end{array}$ & S. para. & $\begin{array}{c}\text { Se. } \\
\text { mar. }\end{array}$ & $\begin{array}{c}\text { Sh. } \\
\text { flex. }\end{array}$ & $\begin{array}{c}\text { Sh. } \\
\text { spp. }\end{array}$ \\
\hline $\begin{array}{c}\text { Add boiling } \\
\text { water }\end{array}$ & 13 & 21 & 11 & 12 & 19 & 17 & 12 & 12 & 15 & 11 \\
\hline $\begin{array}{c}\text { Add boiling } \\
\text { water, left for } \\
10 \text { min. }\end{array}$ & 13 & 17 & 11 & 12 & 19 & 12 & 10 & 13 & 18 & 12 \\
\hline Add cold water & 0 & 14 & 0 & 10 & 13 & 12 & 0 & 0 & 11 & 15 \\
\hline $\begin{array}{c}\text { Add cold } \\
\text { water, left for } 6 \\
\text { h. }\end{array}$ & 13 & 17 & 12 & 14 & 17 & 12 & 10 & 14 & 16 & 13 \\
\hline $\begin{array}{c}\text { Add cold } \\
\text { water, left } \\
\text { for12 h. }\end{array}$ & 15 & 19 & 12 & 18 & 20 & 12 & 10 & 16 & 16 & 16 \\
\hline $\begin{array}{c}\text { Add cold } \\
\text { water, left for } \\
18 \mathrm{~h} .\end{array}$ & 13 & 19 & 12 & 12 & 20 & 13 & 11 & 16 & 12 & 15 \\
\hline $\begin{array}{c}\text { Add cold } \\
\text { water, loft } \\
\text { for24 } \mathrm{h} .\end{array}$ & 14 & 19 & 13 & 14 & 20 & 15 & 15 & 10 & 14 & 14 \\
\hline
\end{tabular}


Afaf A. Amin et al

Table (3) Antibacterial activity (as inhibition zone) of KARKADE extracts on the tested organisms

\begin{tabular}{|c|c|c|c|c|c|c|c|c|c|c|}
\hline $\begin{array}{l}\text { The different } \\
\text { methods used }\end{array}$ & $\begin{array}{c}\text { A. } \\
\text { hydr. }\end{array}$ & $\begin{array}{l}\text { B. } \\
\text { cer. }\end{array}$ & $\begin{array}{l}\mathrm{Ae} . \\
\text { aer. }\end{array}$ & E. coli & Ps. Spp. & $\begin{array}{c}\text { S. } \\
\text { typhim. }\end{array}$ & S para. & $\begin{array}{l}\text { Se. } \\
\text { mar. }\end{array}$ & $\begin{array}{l}\text { Sh. } \\
\text { flex. }\end{array}$ & $\begin{array}{l}\text { Sh. } \\
\text { spp. }\end{array}$ \\
\hline $\begin{array}{l}\text { Add boilling } \\
\text { water }\end{array}$ & 14 & 40 & 15 & 10 & 21 & 14 & 19 & 16 & 18 & 21 \\
\hline $\begin{array}{c}\text { Add boiling } \\
\text { water, left for } \\
10 \mathrm{~min} .\end{array}$ & 15 & 39 & 14 & 20 & 18 & 14 & 20 & 12 & 19 & 24 \\
\hline Add cold water & 11 & 20 & 11 & 17 & 19 & 12 & 16 & 15 & 18 & 20 \\
\hline $\begin{array}{c}\text { Add cold } \\
\text { water, left for } 6 \\
\text { h. }\end{array}$ & 10 & 21 & 12 & 19 & 20 & 13 & 15 & 15 & 22 & 19 \\
\hline $\begin{array}{c}\text { Add cold } \\
\text { water, teft for } \\
12 \mathrm{~h} .\end{array}$ & 15 & 36 & 17 & 18 & 19 & 13 & 12 & 15 & 28 & 15 \\
\hline $\begin{array}{c}\text { Add cold } \\
\text { water, left for } \\
18 \mathrm{~h} .\end{array}$ & 14 & 35 & 12 & 21 & 21 & 15 & 13 & 13 & 17 & 17 \\
\hline $\begin{array}{c}\text { Add cold } \\
\text { water, left for } \\
24 \mathrm{~h} .\end{array}$ & 13 & 36 & 15 & 20 & 20 & 15 & 15 & 15 & 20 & 15 \\
\hline
\end{tabular}

Table (4): Antibacterial activity (as inhibition zone) of CAROB extracts on the tested organisms

\begin{tabular}{|c|c|c|c|c|c|c|c|c|c|c|}
\hline $\begin{array}{l}\text { The different } \\
\text { methods used }\end{array}$ & $\begin{array}{c}\text { A. } \\
\text { hydr. }\end{array}$ & $\begin{array}{l}\text { B. } \\
\text { cer. }\end{array}$ & $\begin{array}{l}\mathrm{Ae} . \\
\text { aer. }\end{array}$ & E. coli & Ps. Spp. & $\begin{array}{c}\text { S. } \\
\text { typhim. }\end{array}$ & S. para. & $\begin{array}{l}\text { Se. } \\
\text { mar. }\end{array}$ & $\begin{array}{l}\text { Sh. } \\
\text { flex. }\end{array}$ & $\begin{array}{l}\text { Sh. } \\
\text { spp. }\end{array}$ \\
\hline $\begin{array}{c}\text { Add bolling } \\
\text { water }\end{array}$ & 0 & 35 & 14 & 10 & 11 & 0 & 12 & 0 & 16 & 13 \\
\hline $\begin{array}{c}\text { Add bolling } \\
\text { water, left for } \\
10 \mathrm{~min} .\end{array}$ & 0 & 35 & 14 & 10 & 12 & 10 & 0 & 0 & 17 & 11 \\
\hline Add cold water & 0 & 21 & 0 & 10 & 0 & 0 & 0 & 0 & 17 & 0 \\
\hline $\begin{array}{c}\text { Add cold } \\
\text { water, left for } 6 \\
\text { h. }\end{array}$ & 0 & 35 & 0 & 10 & 0 & 10 & 0 & 0 & 20 & 10 \\
\hline $\begin{array}{l}\text { Add cold } \\
\text { water, left } \\
\text { for12 h. }\end{array}$ & 0 & 40 & 0 & 10 & 0 & 0 & 0 & 0 & 19 & 0 \\
\hline $\begin{array}{c}\text { Add cold } \\
\text { water, left for } \\
18 \mathrm{~h} .\end{array}$ & 0 & 42 & 0 & 10 & 0 & 0 & 0 & 0 & 19 & 0 \\
\hline $\begin{array}{l}\text { Add cold } \\
\text { water, left } \\
\text { for } 24 \mathrm{~h} \text {. }\end{array}$ & 0 & 21 & 0 & 10 & 0 & 0 & 0 & 0 & 17 & 0 \\
\hline
\end{tabular}

Results are reported as inhibition zones (IZ;mm.) 
Egyptian J. of Nutrition and Health Vol. 1 No. 1 (2006)

Table (5): Comparison between the effects of the investigated plants on Aeromonas hydrophila

\begin{tabular}{|c|c|c|c|c|}
\hline $\begin{array}{c}\text { The methods } \\
\text { used }\end{array}$ & KARKADE & TAMARIND & LIQUORICE & CAROB \\
\hline Add boiling water & 14 & 13 & 16 & 0 \\
\hline $\begin{array}{c}\text { Add boiling water } \\
\text { left for } 10 \text { min. }\end{array}$ & 15 & 13 & 16 & 0 \\
\hline Add cold water & 11 & 0 & 13 & 0 \\
\hline $\begin{array}{c}\text { Add cold water } \\
\text {,left for } 6 \mathrm{~h} .\end{array}$ & 10 & 13 & 16 & 0 \\
\hline $\begin{array}{c}\text { Add cold water } \\
\text { left for } 12 \mathrm{~h} .\end{array}$ & 15 & 15 & 10 & 0 \\
\hline $\begin{array}{c}\text { Add cold water } \\
\text { left for } 18 \mathrm{~h} .\end{array}$ & 14 & 13 & 10 & 0 \\
\hline $\begin{array}{c}\text { Add cold water } \\
\text { left for } 24 \mathrm{~h} .\end{array}$ & 13 & 14 & & 0 \\
\hline
\end{tabular}

Table( 6 ): Comparison between the effects of the investigated plants on BACILLUS CEREUS

\begin{tabular}{|c|c|c|c|c|}
\hline $\begin{array}{c}\text { The methods } \\
\text { used }\end{array}$ & KARKADE & TAMARIND & LIQUORICE & CAROB \\
\hline $\begin{array}{c}\text { Add boiling } \\
\text { water }\end{array}$ & 40 & 21 & 21 & 35 \\
\hline $\begin{array}{c}\text { Add boiling } \\
\text { water , left for } 10 \\
\text { min. }\end{array}$ & 39 & 17 & 22 & 35 \\
\hline Add cold water & 20 & 14 & 23 & 21 \\
\hline $\begin{array}{c}\text { Add cold water } \\
\text { left for } 6 \mathrm{~h} .\end{array}$ & 21 & 17 & 13 & 35 \\
\hline $\begin{array}{c}\text { Add cold water } \\
\text {,left for } 12 \mathrm{~h} .\end{array}$ & 36 & 19 & 15 & 40 \\
\hline $\begin{array}{c}\text { Add cold water } \\
\text {,left for } 18 \mathrm{~h} .\end{array}$ & 35 & 19 & 16 & 21 \\
\hline $\begin{array}{c}\text { Add cold water } \\
\text {,left for } 24 \mathrm{~h} .\end{array}$ & 36 & 19 & 15 & 42 \\
\hline
\end{tabular}


Afaf A. Amin et al

Table (7): Comparison between the effects of the investigated plants on AEROBACTER AEROGENES

\begin{tabular}{|c|c|c|c|c|}
\hline $\begin{array}{c}\text { The methods } \\
\text { used }\end{array}$ & KARKADE & TAMARIND & LIQUORICE & CAROB \\
\hline $\begin{array}{c}\text { Add boiling } \\
\text { water }\end{array}$ & 15 & 11 & 14 & 14 \\
\hline $\begin{array}{c}\text { Add boiling } \\
\text { water left for } 10 \\
\text { min. }\end{array}$ & 14 & 11 & 15 & 14 \\
\hline Add cold water & 11 & 0 & 20 & 0 \\
\hline $\begin{array}{c}\text { Add cold water } \\
\text { left for } 6 \mathrm{~h} .\end{array}$ & 12 & 12 & 16 & 0 \\
\hline $\begin{array}{c}\text { Add cold water } \\
\text { left for } 12 \mathrm{~h} .\end{array}$ & 17 & 12 & 16 & 0 \\
\hline $\begin{array}{c}\text { Add cold water } \\
\text { left for } 18 \mathrm{~h} .\end{array}$ & 12 & 12 & 20 & 0 \\
\hline $\begin{array}{c}\text { Add cold water } \\
\text { left for } 24 \mathrm{~h} .\end{array}$ & 15 & 13 & 16 & 0 \\
\hline
\end{tabular}

Table (8): Comparison between the effects of the investigated plants on $\mathrm{E}$. COLI

\begin{tabular}{|c|c|c|c|c|}
\hline $\begin{array}{c}\text { The methods } \\
\text { used }\end{array}$ & KARKADE & TAMARIND & LIQUORICE & CAROB \\
\hline $\begin{array}{c}\text { Add boiling } \\
\text { water }\end{array}$ & 10 & 12 & 10 & 10 \\
\hline $\begin{array}{c}\text { Add boiling } \\
\text { water , left for } 10 \\
\text { min. }\end{array}$ & 20 & 12 & 10 & 10 \\
\hline Add cold water & 17 & 10 & 10 & 10 \\
\hline $\begin{array}{c}\text { Add cold water } \\
\text { left for } 6 \mathrm{~h} .\end{array}$ & 19 & 14 & 10 & 10 \\
\hline $\begin{array}{c}\text { Add cold water } \\
\text { left for } 12 \mathrm{~h} .\end{array}$ & 18 & 18 & 10 & 10 \\
\hline $\begin{array}{c}\text { Add cold water } \\
\text { left for } 18 \mathrm{~h} .\end{array}$ & 21 & 12 & 10 & 10 \\
\hline $\begin{array}{c}\text { Add cold water } \\
\text { left for } 24 \mathrm{~h} .\end{array}$ & 20 & 14 & & 10 \\
\hline
\end{tabular}


Egyptian J. of Nutrition and Health Vol. 1 No. 1 (2006)

Table (9): Comparison between the effects of the investigated plants on Pseudomonas Sp.

\begin{tabular}{|c|c|c|c|c|}
\hline $\begin{array}{c}\text { The methods } \\
\text { used }\end{array}$ & KARKADE & TAMARIND & LIQUORICE & CAROB \\
\hline $\begin{array}{c}\text { Add boiling } \\
\text { water }\end{array}$ & 21 & 19 & 20 & 11 \\
\hline $\begin{array}{c}\text { Add boiling water } \\
\text {,left for } 10 \text { min. }\end{array}$ & 18 & 19 & 19 & 12 \\
\hline Add cold water & 19 & 13 & 11 & 0 \\
\hline $\begin{array}{c}\text { Add cold water } \\
\text {,left for } 6 \mathrm{~h} .\end{array}$ & 20 & 17 & 15 & 0 \\
\hline $\begin{array}{c}\text { Add cold water } \\
\text { left for } 12 \mathrm{~h} .\end{array}$ & 19 & 20 & 13 & 0 \\
\hline $\begin{array}{c}\text { Add cold water } \\
\text { left for } 18 \mathrm{~h} .\end{array}$ & 21 & 20 & 13 & 0 \\
\hline $\begin{array}{c}\text { Add cold water } \\
\text { left for } 24 \mathrm{~h} .\end{array}$ & 20 & 20 & & \\
\hline
\end{tabular}

Table (10): Comparison between the effects of the investigated plants on Salmonella Typhimurium

\begin{tabular}{|c|c|c|c|c|}
\hline $\begin{array}{c}\text { The methods } \\
\text { used }\end{array}$ & KARKADE & TAMARIND & LIQUORICE & CAROB \\
\hline $\begin{array}{c}\text { Add boiling } \\
\text { water }\end{array}$ & 14 & 17 & 23 & 0 \\
\hline $\begin{array}{c}\text { Add boiling } \\
\text { water left for } 10 \\
\text { min. }\end{array}$ & 14 & 12 & 20 & 10 \\
\hline Add cold water & 12 & 12 & 14 & 0 \\
\hline $\begin{array}{c}\text { Add cold water } \\
\text { left for } 6 \mathrm{~h} .\end{array}$ & 13 & 12 & 17 & 10 \\
\hline $\begin{array}{c}\text { Add cold water } \\
\text {,left for } 12 \mathrm{~h} .\end{array}$ & 13 & 12 & 20 & 0 \\
\hline $\begin{array}{c}\text { Add cold water } \\
\text { left for } 18 \mathrm{~h} .\end{array}$ & 15 & 13 & 17 & 0 \\
\hline $\begin{array}{c}\text { Add cold water } \\
\text { left for } 24 \mathrm{~h} .\end{array}$ & 15 & 15 & 16 & 0 \\
\hline
\end{tabular}


Afaf A. Amin et al

Table (11): Comparison between the effects of the investigated plants on Salmonella Paratyphi

\begin{tabular}{|c|c|c|c|c|}
\hline $\begin{array}{c}\text { The methods } \\
\text { used }\end{array}$ & KARKADE & TAMARIND & LIQUÓRICE & CAROB \\
\hline $\begin{array}{c}\text { Add boiling } \\
\text { water }\end{array}$ & 19 & 12 & 15 & 0 \\
\hline $\begin{array}{c}\text { Add boiling } \\
\text { water , left for } 10 \\
\text { min. }\end{array}$ & 20 & 10 & 20 & 10 \\
\hline \begin{tabular}{c} 
Add cold water \\
\hline $\begin{array}{c}\text { Add cold water } \\
\text { left for } 6 \mathrm{~h} .\end{array}$
\end{tabular}$\quad 16$ & 0 & 14 & 0 \\
\hline $\begin{array}{c}\text { Add cold water } \\
\text {,left for } 12 \mathrm{~h} .\end{array}$ & 12 & 10 & 15 & 10 \\
\hline $\begin{array}{c}\text { Add cold water } \\
\text {,left for } 18 \mathrm{~h} .\end{array}$ & 13 & 11 & 15 & 0 \\
\hline $\begin{array}{c}\text { Add cold water } \\
\text { left for } 24 \mathrm{~h} .\end{array}$ & 15 & 15 & 20 & 0 \\
\hline
\end{tabular}

Table (12): Comparison between the effects of the investigated plants on Serratia Marcescens

\begin{tabular}{|c|c|c|c|c|}
\hline $\begin{array}{c}\text { The methods } \\
\text { used }\end{array}$ & KARKADE & TAMARIND & LIQUORICE & CAROB \\
\hline $\begin{array}{c}\text { Add boiling } \\
\text { water }\end{array}$ & 15 & 0 & 11 & 0 \\
\hline $\begin{array}{c}\text { Add boiling water } \\
\text { left for } 10 \text { min. }\end{array}$ & 16 & 13 & 13 & 0 \\
\hline Add cold water & 12 & 13 & 13 & 0 \\
\hline $\begin{array}{c}\text { Add cold water } \\
\text {,left for } 6 \mathrm{~h} .\end{array}$ & 15 & 13 & 16 & 0 \\
\hline $\begin{array}{c}\text { Add cold water } \\
\text {,left for } 12 \mathrm{~h} .\end{array}$ & 15 & 15 & 16 & 0 \\
\hline $\begin{array}{c}\text { Add cold water } \\
\text {,left for } 18 \mathrm{~h} .\end{array}$ & 13 & 13 & 12 & 0 \\
\hline $\begin{array}{c}\text { Add cold water } \\
\text { left for } 24 \mathrm{~h} .\end{array}$ & 15 & 14 & & 0 \\
\hline
\end{tabular}


Egyptian J. of Nutrition and Health Vol. 1 No. 1 (2006)

Table (13): Comparison between the effects of the investigated plants on Shigella Flexenary

\begin{tabular}{|c|c|c|c|c|}
\hline $\begin{array}{c}\text { The methods } \\
\text { used }\end{array}$ & KARKADE & TAMARIND & LIQUORICE & CAROB \\
\hline $\begin{array}{c}\text { Add bolling } \\
\text { water }\end{array}$ & 18 & 15 & 10 & 16 \\
\hline $\begin{array}{c}\text { Add boiling } \\
\text { water , left for } 10 \\
\text { min. }\end{array}$ & 19 & 18 & 10 & 17 \\
\hline $\begin{array}{c}\text { Add cold water } \\
\text { Add cold water } \\
\text {,left for } 6 \mathrm{~h} .\end{array}$ & 18 & 11 & 10 & 17 \\
\hline $\begin{array}{c}\text { Add cold water } \\
\text {,left for } 12 \mathrm{~h} .\end{array}$ & 28 & 16 & 11 & 20 \\
\hline $\begin{array}{c}\text { Add cold water } \\
\text { left for } 18 \mathrm{~h} .\end{array}$ & 17 & 12 & 13 & 19 \\
\hline $\begin{array}{c}\text { Add cold water } \\
\text {,left for } 24 \mathrm{~h} .\end{array}$ & 20 & 14 & 10 & 17 \\
\hline
\end{tabular}

Table (14) : Comparison between the effects of the investigated plants on Shigella Sp.

\begin{tabular}{|c|c|c|c|c|}
\hline $\begin{array}{c}\text { The methods } \\
\text { used }\end{array}$ & KARKADE & TAMARIND & LIQUORICE & CAROB \\
\hline $\begin{array}{c}\text { Add boiling } \\
\text { water }\end{array}$ & 21 & 11 & 12 & 13 \\
\hline $\begin{array}{c}\text { Add boiling } \\
\text { water ,left for } 10 \\
\text { min. }\end{array}$ & 24 & 12 & 12 & 11 \\
\hline Add cold water & 20 & 15 & 15 & 0 \\
\hline $\begin{array}{c}\text { Add cold water } \\
\text { left for } 6 \mathrm{~h} .\end{array}$ & 19 & 13 & 15 & 10 \\
\hline $\begin{array}{c}\text { Add cold water } \\
\text {,left for } 12 \mathrm{~h} .\end{array}$ & 15 & 16 & 15 & 0 \\
\hline $\begin{array}{c}\text { Add cold water } \\
\text {,left for } 18 \mathrm{~h} .\end{array}$ & 17 & 15 & 18 & 0 \\
\hline $\begin{array}{c}\text { Add cold water } \\
\text {,left for } 24 \mathrm{~h} .\end{array}$ & 15 & 15 & 15 & 0 \\
\hline
\end{tabular}




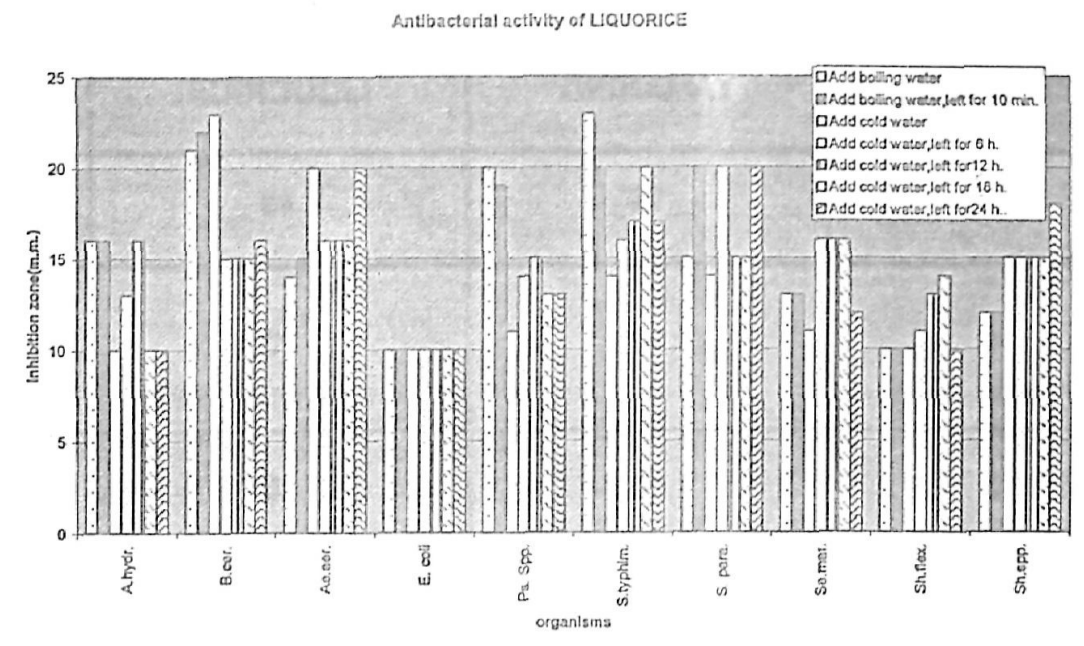

Figure 1

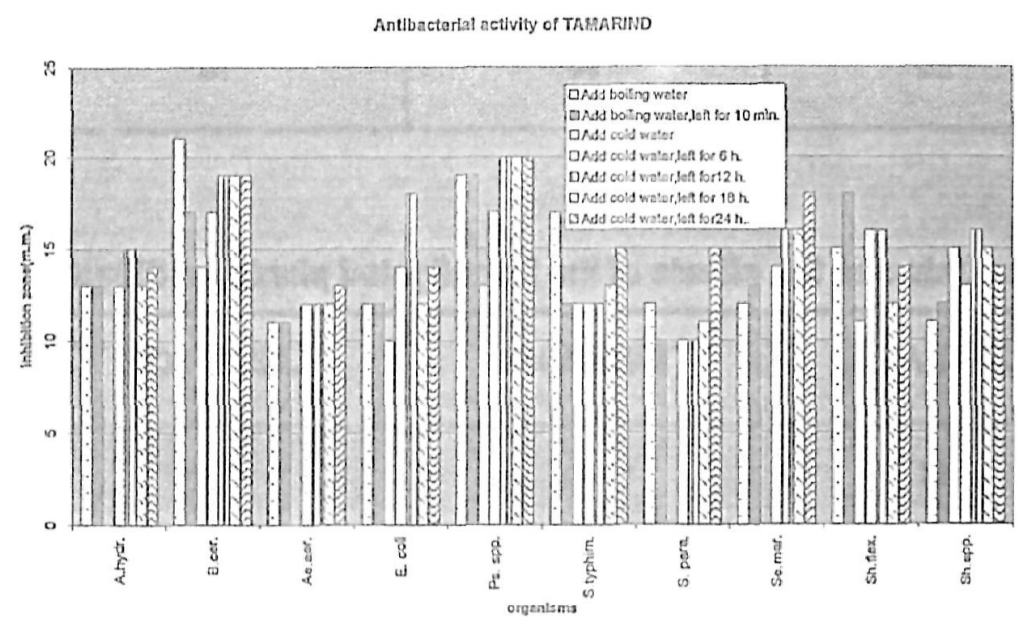

Figure 2 
Egyptian d. of Nutrition and Health Vol. 1 No. 1 (2006)

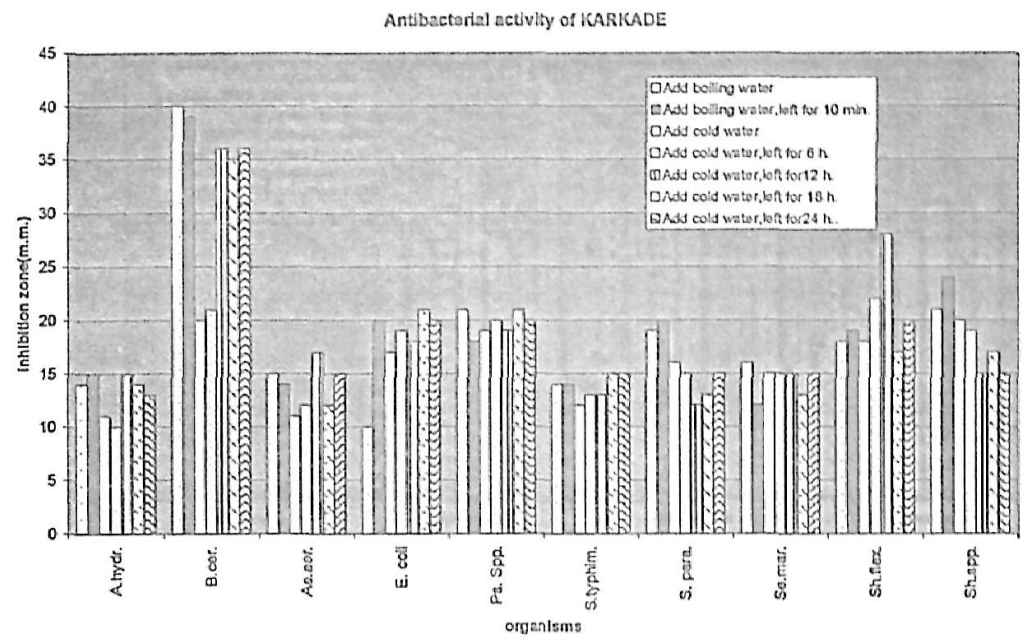

Figure 3

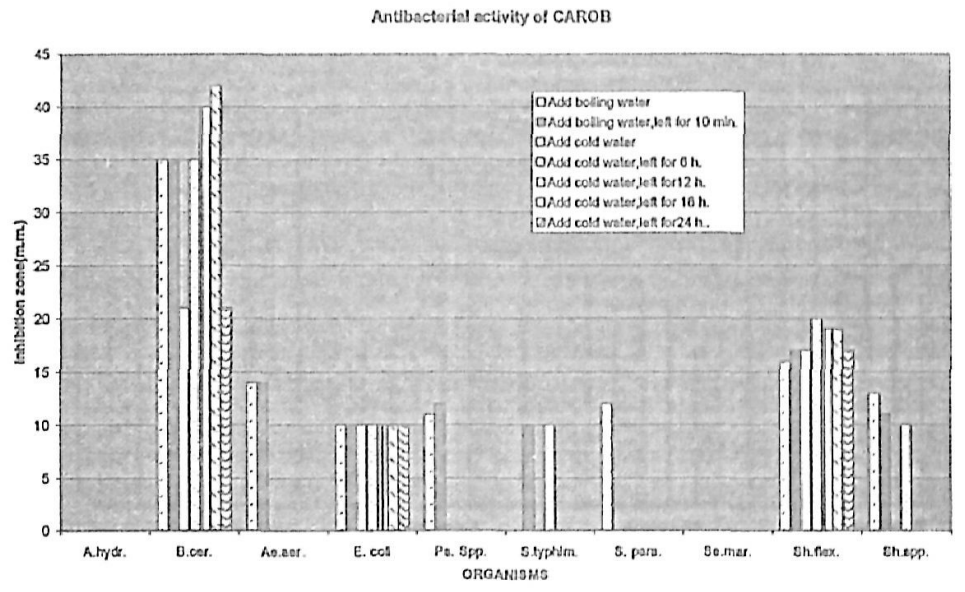

Figure 4 


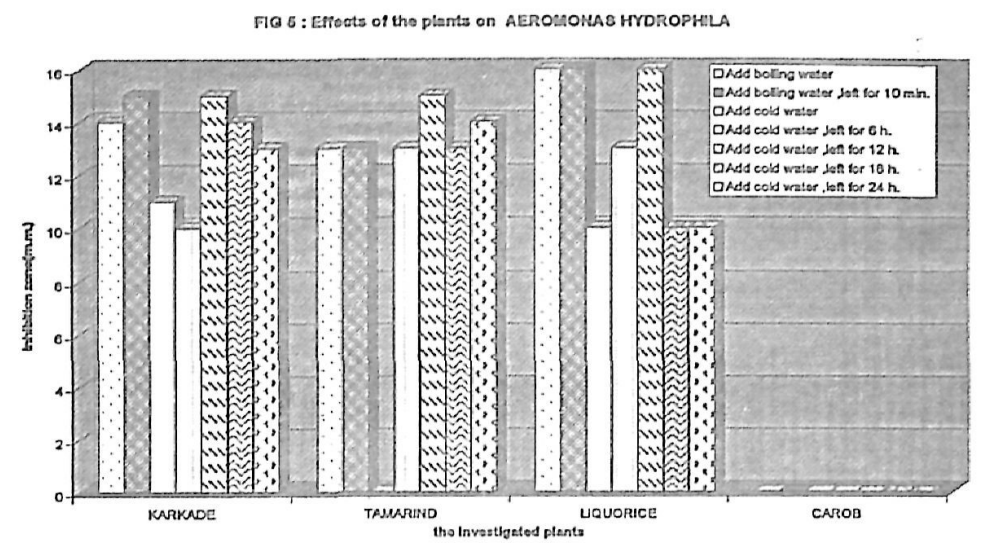

Figure 5

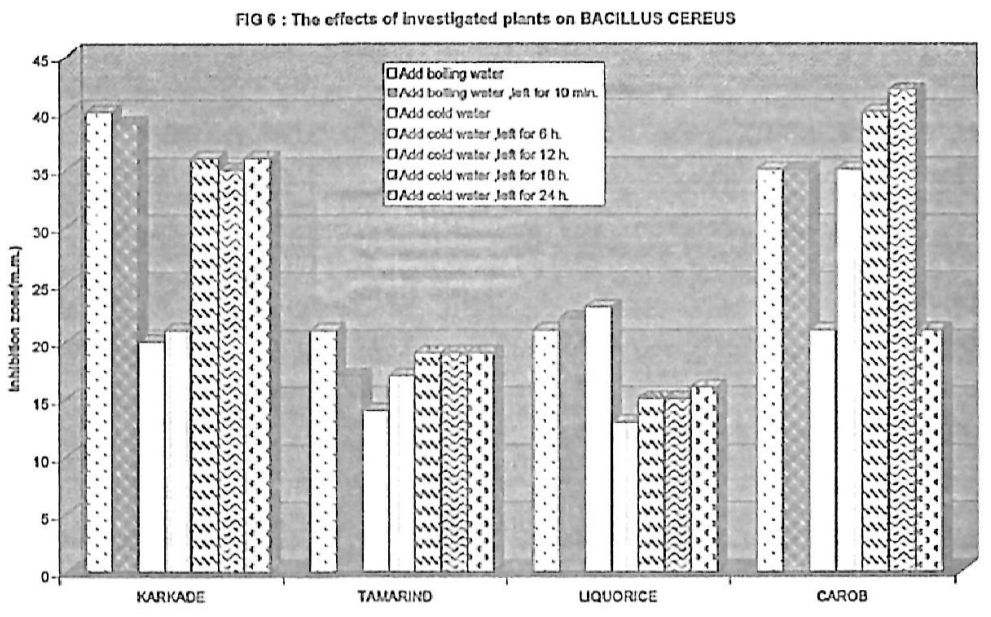

Figure 6 
Egyptian J. of Nutrition and Health Vol. 1 No. 1 (2006)

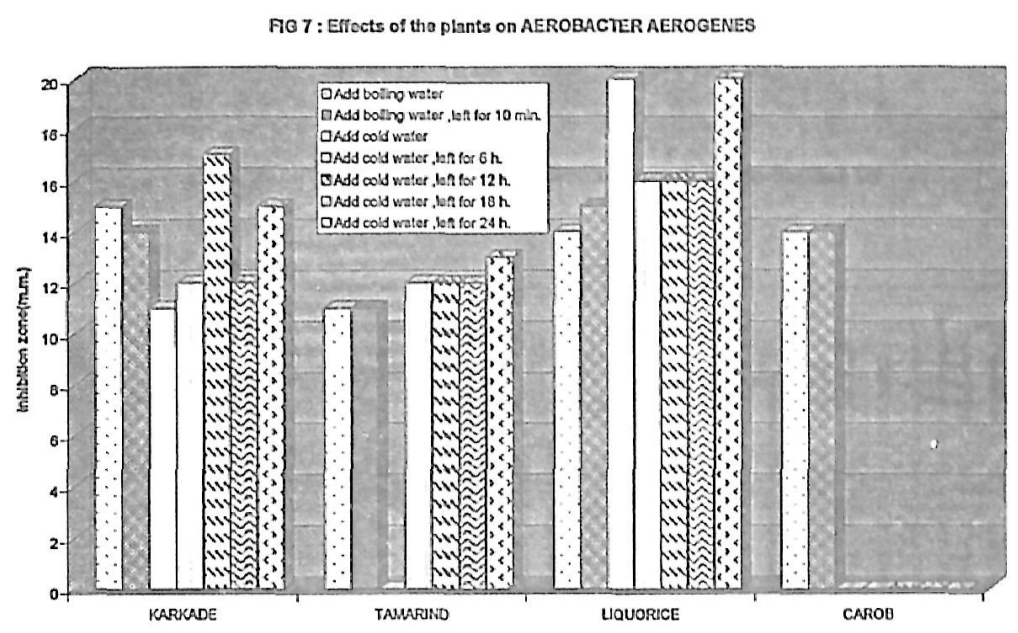

Figure 7

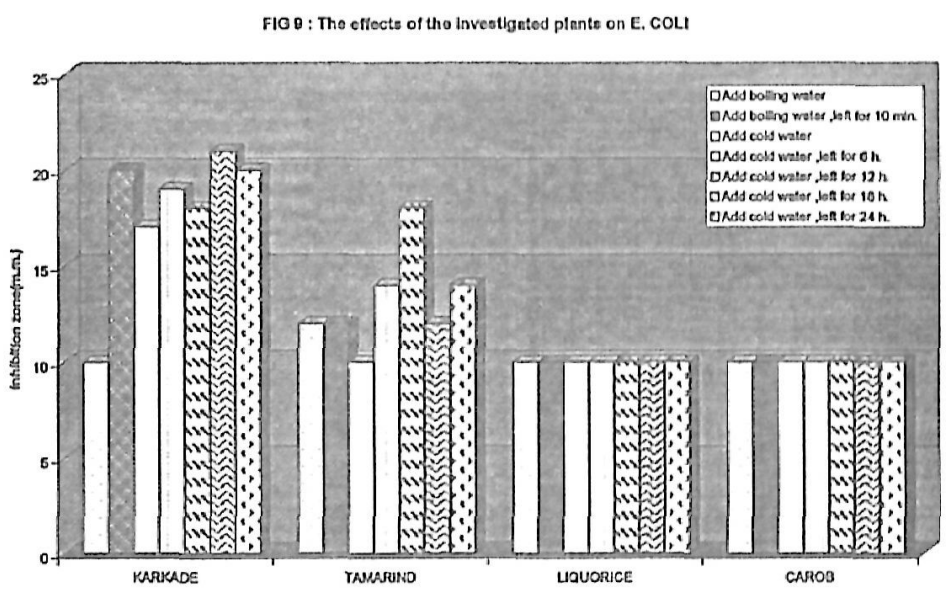

Figure 8 
F10 8 : Eflocts of tha 4 plents on PSEUDOMONAS ap.

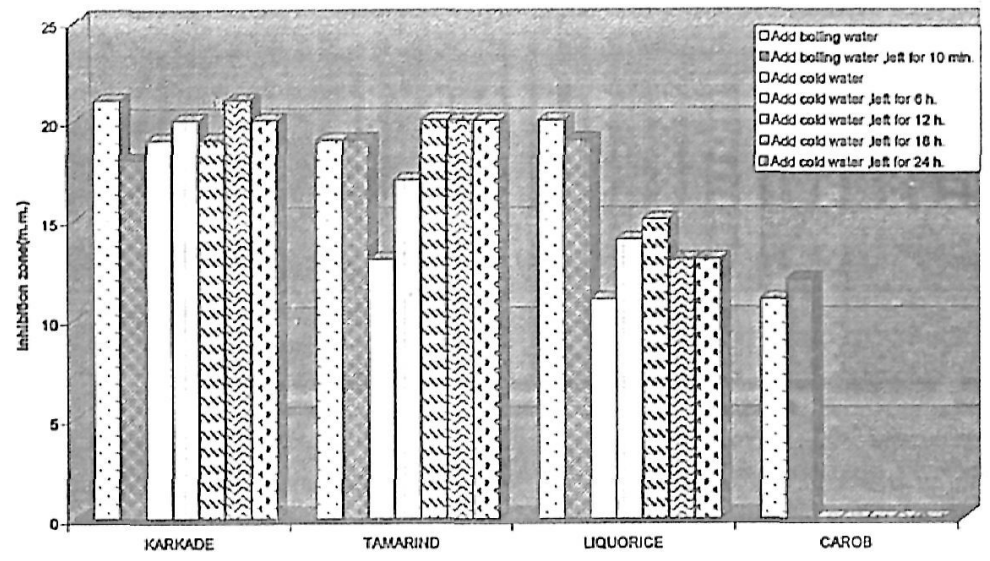

Figure 9

FIG 10 : Effocts of the 4 plants on SALMONELLA TYPHIMURUA

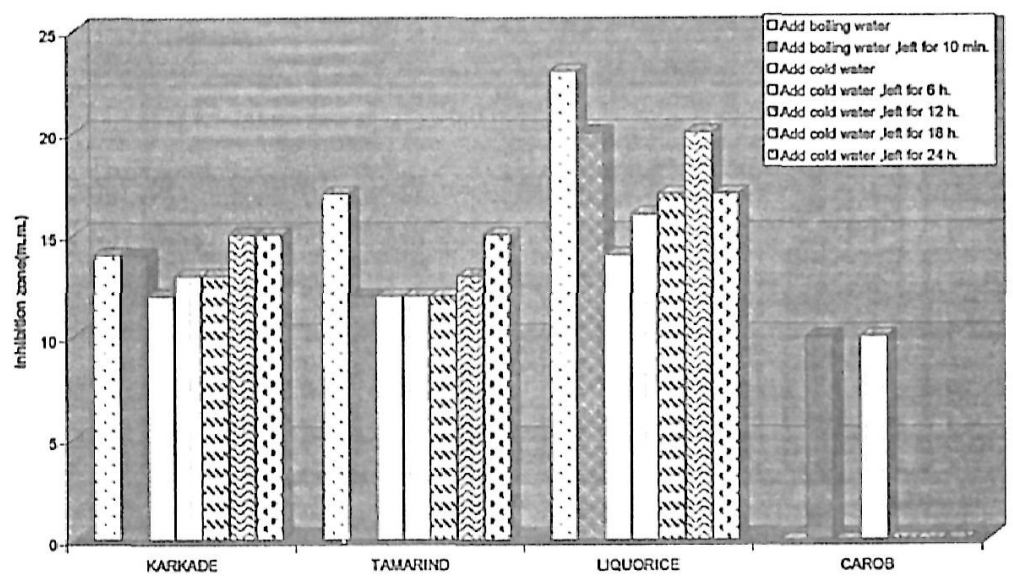

Figure 10 


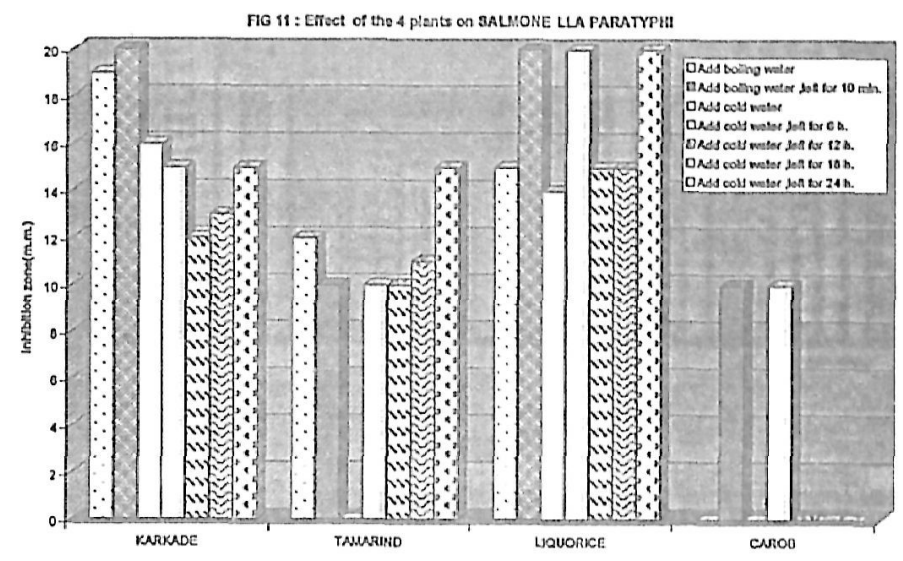

Figure 11

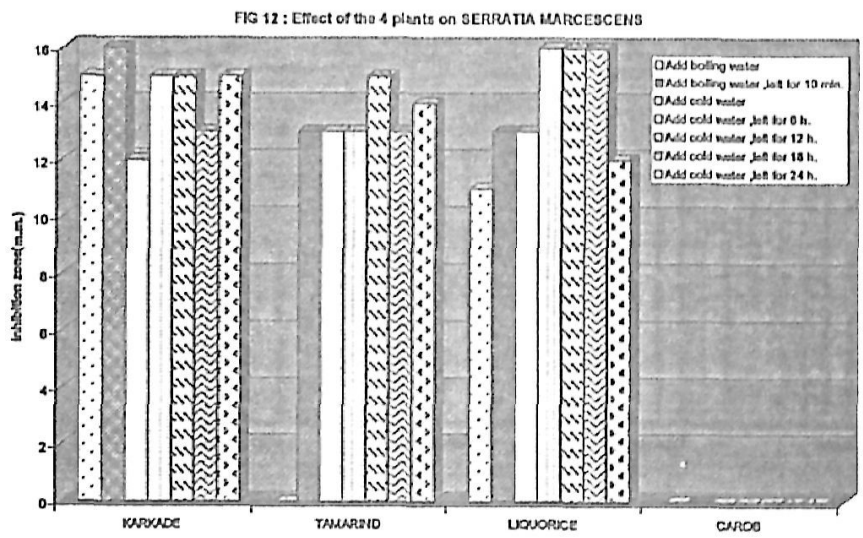

Figure 12 


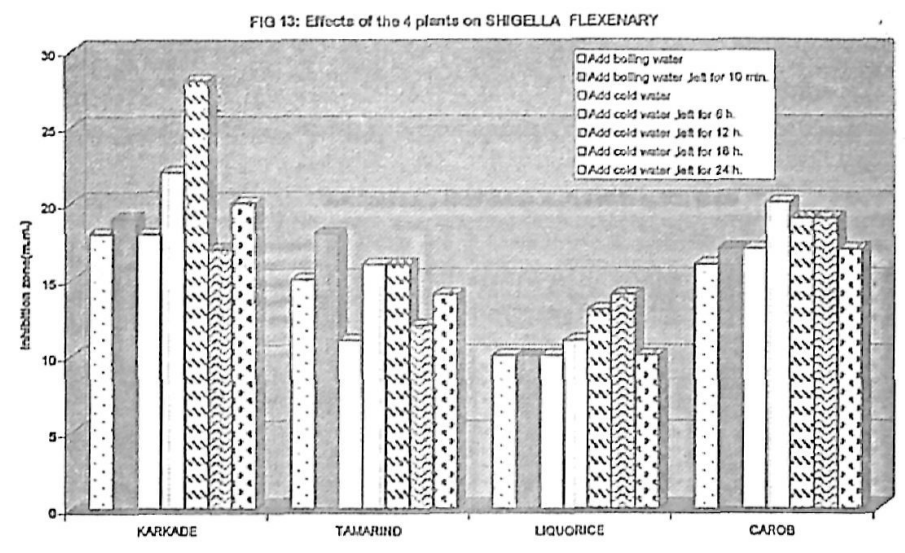

Figure 13

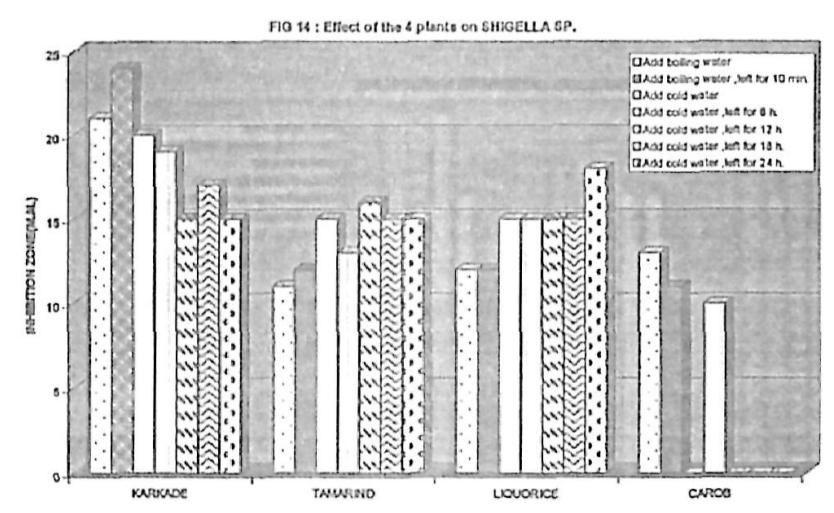

Figure 14

\section{Acknowledgement}

Authors would like to acknowledge the director of NNI Dr. Azza Gohar and Pr. Dr.Reda ElSherbeny for their continuous support while conducting this work.

We also thank Miss Amira A. A. Hamed and Mr.Ahmed H. Saied for technical assistance. 
Egyptian J. of Nutrition and Health Vol. 1 No. 1 (2006)

\section{References}

Aboaba O.O., Smith S.I. and Olude F.O. (2006):Antibacterial Effect of Edible Plant Extract on Escherichia coli O157:H7. Pakistan Journal of Nutrition 5 (4):325-327.

Abo El-Azm,A. (1999): Microbiological Studies on Some Medical Plants.

Msc. Thesis . Home Economic Menoufia Univ.

Abou-Zeid, A.A. and Shehata, Y.M. (1969) :A Simple Technique for Assaying Antibiotic Using Methylene blue as an Indicator. The Indian Journal of Pharmacy, 31, 72.

Ajagbonna, OP, Ajagbonna, HO, Olorede, BR (2001) :Antibacterial Properties of Calyx, Stem Bark and Root of Hibiscus sabdariffa. Nigerian Journal of Natural Products and Medicine, Vol. 5

Alian A ., El-Ashwah and Eid, N (1983) :Antimicrobial Properties of some Egyptian Non-alcoholic Beverages with Special reference toTamarind. Egyptian Journal of Food Science, 11 (12) 109-114.

Amer , M. and Metwalli , M. (2000) :Topical Liquiritin Improves Melasma . Int. J .Dermatol 39: 299301.

Ates D. Ayfer, Erdogrul Ozlem Turgay (2003) :Antimicrobial Activities of Various Medicinal and Commercial Plant Extracts Turk J Biol 27, 157-162.

Beil, w., Birlchols, c. and Sewing, K.F. (1995) :Effect of Flavonoids on Parietal Cell Acid Secretion, Gastric Mucosal Prostaglandin Production and Heiicobacter pylori Growth.Arzneim Forsch 45: $697-700$.

Bepoliver - bevere (1986) :Medicinal Plants in Tropical West Africa.Cambridge Univ. Press. Londion, New Rochelle, Melbourne, Sydney.

C.A.P.A. (2000): Guidelines for Quality Control of Herbal Medicines.

Central Administration of Pharmaceutical Affairs, Ministry of Health. WHO, Cairo, Egypt. Faculty of Pharmacy. Cairo Univ.

Dryden, Gerald, W, Song, Ming, McClain Craig (2006):Polyphenols and Gastrointestinal Diseases.Current Opinion in Gastroenterology, 22 (2): 165-170. 
Evans CE, Banso A, Samuel OA. : (2002)

Efficacy of some nape medicinal plants against Salmonella typhi: an in vitro study.J Ethnopharmacol , 80(1): $21-4$

Frus - Moller , A. , Chen , M. , Fuursted , K. , Christensen , S.B. and Kharazmi A. (2002):

In Vetro Antimycobacterial and Antilegionella Activity of Licochalcone A from Chinese Licorice roots.Planta-Medica 68 (5) : 416-419.

Gamal , N.F. (1992) :Antibacterial Activity of Liquorice Water Extract in Relation to Different Saponin Concentration. Annals of Agric. Sc. Moshtohor, Vol. 30 (1) 425-434.

Ganamani A. , Priya K.S. , Radhakrishnan N. , Mary B. (3003) :Antibacterial Activity of Two Plant Extract on Eight Burn Pathogens. Journal of Ethno pharmacology 86 (1): 59-61.

Haraguchi, H., Tanimoto, K., Tamura, Y., Mizutani, K. And Kinoshita, T. (1998):Mode of Antibacterial Action of Retrochalcones from Glycyrrhiza inflates.Phytochemistry , 48 (1) 125-129.

I.C.M.S.F. (1980):International Commission on Microbiological Specifications for foods.Microbiol Ecology of Foods Vol. 2 Food Commodities. Academic Press.

Imbabi, E.S., Ibrahim, K.E., Ahmed, B.M., Abulfutuh, I.M. and Hulber (1992):Characterization of Tamarind Biltes Principle

Tamarindineol (Tamarindienal) 537-538.Josephs, R.A., Guinn, J.S., Harper, M.L. and Askari, F. (2001):

Liquorice Consumption and Salivary Testosterone Concentrations.Lancet 358 : 1613-4 .

Khan M. R. , Omoloso A. D. , Kihara M. (2003) : Antimicrobial Activity of Artocarpus Heterophyllus, Fitoterapia $74: 501-505$.

Kivcak Bijen, Mert Tuba and Ozturk H. Tansel (2002) :Antimicrobial and Cytotoxic Activities of Ceratonia siliqua L. Extracts. TURK J BIOL 26, 197-200

Leath, K.T., Davis, K.H., Jr, M.E. and Hanson, C.H. (1972):Vegetative growth Response of Alfalfa Pathogens to Saponin and other Extracts from Alfalfa (Medicago sativa).Crop Sci 12, 851856. 
Leob, H., Vandenplus, Y., Wursch , P. , Guesry ,P. (1989) :Tannin-rich Carob Pod for the Treatment of Acute-Onset Diarrhea. J. Pediatric Gastroent Nut .8:480-5.

Liu Keh-sen · Tsao Shyh-ming , Yin Mei-chin: (2005)

In vitro antibacterial activity of roselle calyx and protocatechuic acid Phytotherapy Research Volume 19, Issue11, Pages $942-945$

Matu E. N. and Staden J.V. (2003):Antibacterial and Anti- inflammatory Activities of Some Plants Used for Medicinal Purposes in Kenya. Journal of Ethnopharamacology 87: 35-41.

Moses N. Ngemenya, James A. Mbah, Pierre Tane and Vincent P.K.Titanji (2006): Antibacterial Effects of Some Cameroonian Medicinal Plants against Common Pathogenic Bacteria.African Journal of Traditional, Complementary and Alternative Medicines, Vol. 3 , No. 2, 2006, pp. 84-93

Moshi Mainen J., Mbwambo Zakaria H., Kapingu Modest C., Mhozya Viva H., Marwa Chacha (2006):Antimicrobial and Brine Shrimp Lethality of Extracts of Terminalia mollis Laws African Journal of Traditional, Complementary and Alternative Medicines, Vol. 3, No. 3, pp. 59-69

Muthu SE, Nandakumar S, Rao UA. (2005): The effect of methanolic extract of Tamarindus indica Linn. on the growth of clinical isolates of Burkholderia pseudomallei.Indian J Med Res., $122(6): 525-8$.

Neidhardt, F.C., Ingraham, J.L. and Schaechter, M. (1990):Physiology of the Bacterial Cell. A Medullar Approach. Sinauer, Associates, Inc. Sunderland and Massachusetts, 01375 .USA.

Nkuo-Akenji T, Ndip R, McThomas A, Fru EC. (2001):Anti-Salmonella activity of medicinal plants from Cameroon.Cent Afr J Med.:47(6): 155-8.

Oboh, G. and Elusiyan, C.A. (2004):Nutrient Composition and Antimicrobial Activity of Sorrel Drinks (Soborodo). J.Med Food: 7: 340-2. 
Owulade M. O., Eghianruwa, K. I. and Daramola, F.O. (2004): Effects of Aqueous Extracts of Hibiscus sabdariffa Calyces and Ocimum gratissimum Leaves on Intestinal Transit in Rats. African Journal of Biomedical Research, Vol. 7, No. 1, pp. 31-33.

Ram A. J., Bahakshu L. Md. , Venkata Raju R. R. (2004) :In Vitro Antimicrobial Activity of Certain Medicinal Plants from Eastern Ghats, India, Used for Skin Diseases .Journal of Ethno pharmacology 90: 353-357.

Ray, P.G. and Majumdar, S.K. (1976):Antimicrobial Activity of some Indian Plants.Econ. Bot. (3): 317-320

Ross, S.A., Megalla, S.E., Bishay, D.W. and Awad, A.I. (1980):Studies for Determining Antibiotic Substances in Some Egyptian Plants.Part 1. Screening for Antimicrobial Activity.Fitoterapia, 51: 303-308.

Sahelian, R. (2005):Journal of Natural Products. Supplement Research Update Vol. 2, Issue 4.

Tsukiyama Ryo-Ichi, Katsura Harumi, Tokuriki Nozomu, and Kobayashi Makio (2002):Antibacterial Activity of Licochalcone A against Spore-Forming Bacteria Antimicrob Agents Chemother. 46(5): 1226-1230.

Walker, A. (2006):Strengthening the Evidence Base for Herbal Medicine.

Herbal Medicine: the Science of the Art, Proc Nutr. Soc. 65: 145-152. 
Egyptian J. of Nutrition and Health Vol. 1 No. 1 (2006)

التائير المضاد للمبكريات فم بعض النباتات المصريي

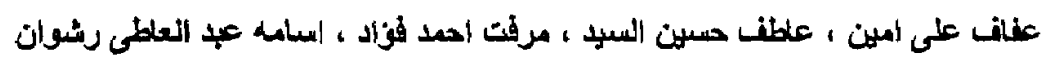

$$
\text { الملخص العزبى }
$$

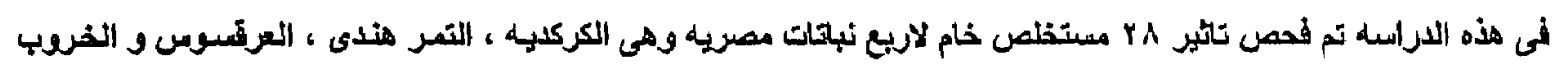

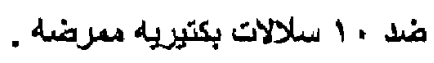

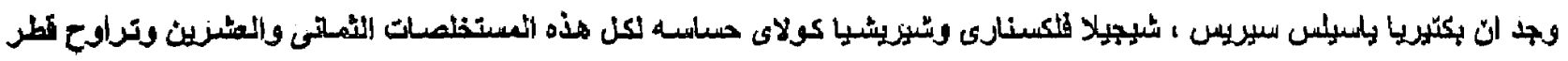

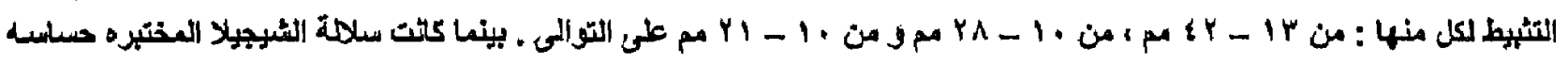

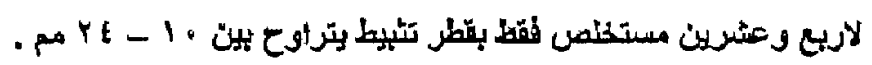

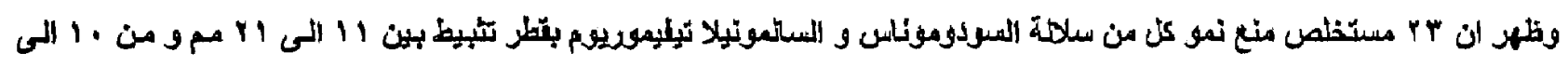

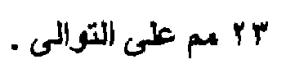

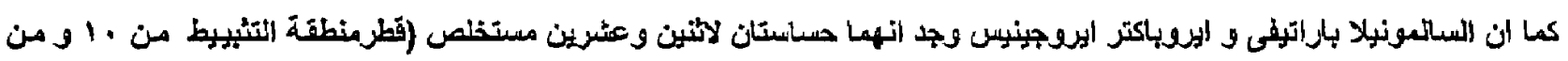

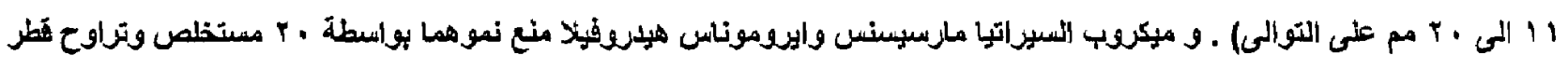

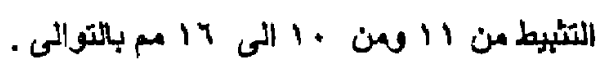

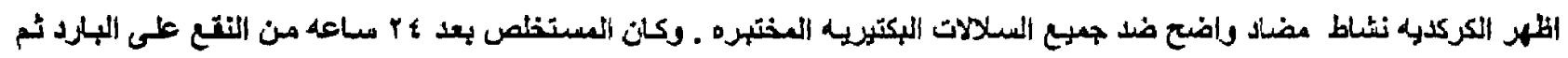

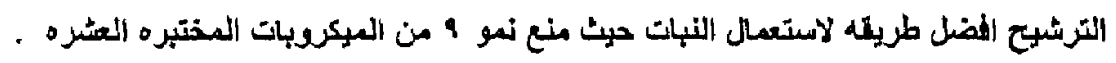

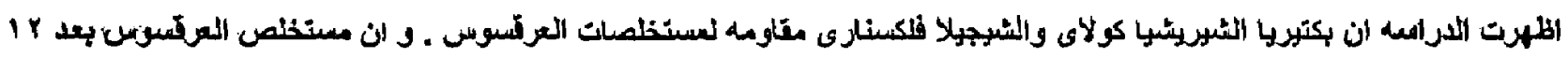

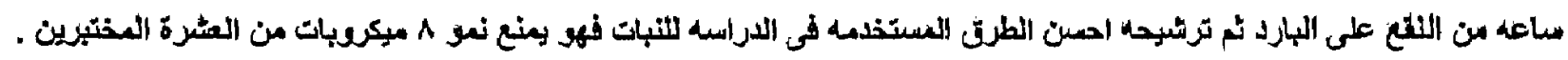

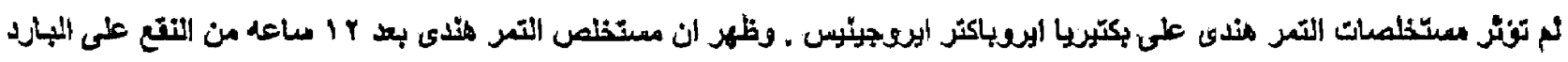

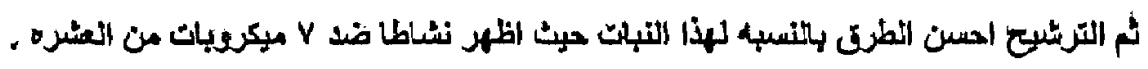

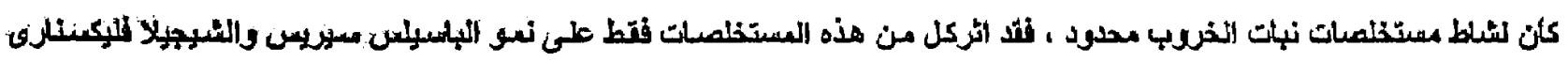

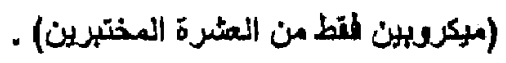

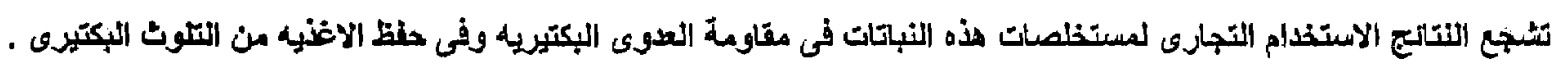

